\title{
Role of acute metal toxicity in structuring seagrass fauna near a lead smelter
}

\author{
Trevor J. Ward \\ Division of Fisheries Research, CSIRO Marine Laboratories, P.O.Box 21, Cronulla, NSW 2230, Australia
}

\begin{abstract}
Field acute toxicity tests over 21 d periods demonstrate that 2 species of vagile epibenthic seagrass fauna (the fish Neoodax sp. and the crustacean Cymodoce longicaudata) are acutely affected by $\mathrm{Cd}, \mathrm{Cu}, \mathrm{Pb}$ or $\mathrm{Zn}$ in the effluent from a lead smelter. By comparison with the laboratory $\mathrm{LC}_{50}$ data in the literature for other marine fishes and crustaceans it appears that $\mathrm{Zn}$ is the metal mainly responsible for these effects. Although $C$. longicaudata is acutely affected by the metals, its abundance is normal in some parts of the highly contaminated area. A third species (the fish Helotes sexlineatus), whilst not acutely affected by the metals in these experiments, was shown by a previous survey to be reduced in abundance in the highly contaminated area. Since the distribution of these latter 2 common species cannot be explained by the results of acute toxicity tests it is unlikely that acute toxicity of these metals is the major determinant of community structure in the highly contaminated area even though the concentrations of $\mathrm{Zn}$ in the smelter effluent appear to be near laboratory-derived $\mathrm{LC}_{50}$ concentrations for other marine species. Outside the highly contaminated area acute toxicity of these metals is unlikely to have any effect on community structure. It is concluded that acute toxicity plays only a minor role in structuring the seagrass faunal communities of the contaminated area and that acute toxicity tests using dissolved metals are unable to predict ecological effects. Therefore, such tests are probably unsuitable as bases for determining water quality criteria for protection of seagrass fauna.
\end{abstract}

\section{INTRODUCTION}

Ecological effects of metals in the coastal marine environment are poorly understood. As a result water quality criteria for the protection of the marine environment have been largely determined by extrapolation from acute and chronic effects of toxicants observed in laboratory tests (Train, 1979). An arbitary 'application factor' is applied to the results of these laboratory toxicity tests, and the resulting concentrations purport to represent 'safe' concentrations, those at which there will be minimum ecological disturbance to marine communities and thereby to species of commercial and recreational significance.

A community parameter of great value in the description of marine habitats is species composition. This parameter may not only be an efficient descriptor of marine biological systems but may also be used to assess accurately the effects of toxicants (Gray and Mirza, 1979) since, if the system has come to equilibrium with the toxicant, the community structure will reflect the results of acute and chronic effects, sublethal effects on growth and reproduction, and such biological effects as behavioural changes and alterations in predator-prey relations.

The assessment of community structure involves substantial sampling difficulties which reduce the ability of community-level studies to assess effects accurately. On the other hand, the numerous biotic and abiotic factors which could be involved in structuring marine communities cannot adequately be simulated or controlled in laboratory tests. Thus, despite their limited resolving power, field studies at the community level can provide a useful assessment of the environmental effects of a contaminant, and it is a widely agreed but seldom practised dogma that changes at the community level are the best overall measures of environmental effects (Sprague, 1971).

Water quality criteria derived from laboratory toxicity tests are of little ecological value since they are usually based on tests on a few, sometimes one, species from a habitat type. These species are often chosen for their recreational or commercial value and not for their ecological significance (e.g. Ahsanullah et al., 1981). Even when species are selected for testing on some a priori basis (e.g. Tarzwell, 1971) these representative 
species do not necessarily reflect the effects in all species of that taxonomic or ecological group. Rather, since similar animals living in adjacent areas can display different body burdens of metals (Boyden and Phillips, 1981), they may be differently affected by a particular metal. Thus, the initial choice of species and its life-stage to be tested can dramatically influence the resultant water criteria. It is apparent then that, except when long-term life cycle tests for each species of a community are performed (Tarzwell, 1971), laboratory tests of toxicity can provide only a crude measure of ecological effect.

In a previous field study 20 species of vagile epibenthic seagrass fauna (fishes and crustaceans) were identified as being eliminated or reduced by $\mathrm{Cd}, \mathrm{Cu}, \mathrm{Mn}$, $\mathrm{Pb}$ or $\mathrm{Zn}$ near a large lead smelter (Ward and Young, 1982). The sediment concentrations of these metals were used as the basis for identification of affected species. However, the type of effect (acute, chronic, sublethal, etc.) could not be determined and the main pathway for transfer of metals to these species was not identified.

The aim of the present study is to assess the contribution of acute toxicity of the metals to the species distribution pattern described by Ward and Young (1982). A series of field experiments were conducted in the contaminated area near the smelter to ensure that results of toxicity tests would be directly comparable with results from the ecological survey.

The study area is located at Port Pirie, Spencer Gulf, South Australia, adjacent to the world's largest lead smelter (Fig. 1). The smelter is set in a rural environment and there is virtually no other contamination of adjacent Gulf waters other than by metals from the smelter. Gulf sediments at the entrance to First Creek, which carry the liquid effluent from the smelter, are contaminated by $\mathrm{Cd}, \mathrm{Cu}, \mathrm{Mn}, \mathrm{Pb}$ and $\mathrm{Zn}$, but $\mathrm{Cu}$ and Mn are only minor contaminants (Ward and Young, 1981). Own drogue studies (unpubl.) show that water from First Creek flows directly over the shallow metalcontaminated seagrass beds (Zostera mucronata, Posidonia australis, $P$. sinuosa) surveyed by Ward and Young (1982), consequently the experiments described here were carried out in First Creek and in Fifth Creek (control).

\section{MATERIALS AND METHODS}

Species to be tested were collected by beam trawling in seagrass beds in an area of low metal contamination about $10 \mathrm{~km}$ south-west of First Creek (near Fifth Creek, Fig. 1). Animals were kept in aerated plastic containers of fresh seawater for periods ranging from 2 to $24 \mathrm{~h}$, after which they were allocated randomly to the experimental cages. Cages were located in First
Creek, about $3 \mathrm{~km}$ downstream of the smelter and $1.5 \mathrm{~km}$ downstream of the upper tidal limit, and about $750 \mathrm{~m}$ upstream from Spencer Gulf. An uncontaminated control site was established in Fifth Creek $(8 \mathrm{~km}$ south-west of First Creek), and here cages were also located about $750 \mathrm{~m}$ upstream from the Gulf. Experimental cages were all plastic $300 \mathrm{~mm}$ diameter spherical clear garden terrariums, modified by the attachment of a removable glass port at the top (for scoring mortalities) and by insertion of two $12 \mathrm{~mm}$ holes covered by fibreglass mesh on opposite upper surfaces to permit water flow through the cage. A truncated polypropylene powder funnel (entrance diameter $20 \mathrm{~mm}$ ) was glued over each hole to reduce entry of solids to the cage. A concrete base about $80 \mathrm{~mm}$ deep was poured in each cage and aged in water for at least $7 \mathrm{~d}$ prior to use in the experiment. The cages were buried about $160 \mathrm{~mm}$ in the sediment and oriented for maximum current flow through the cage. Cages were cleaned only between experiments but algal growth was not excessive. Two experiments were carried out between 9th September and 28th October, 1981. The lead smelter (BHAS Pty. Ltd.) provided results of daily analyses of their liquid effluent, and its metal concentrations and $\mathrm{pH}$ remained steady throughout these experiments. Bottom salinity and temperature were recorded near the cages at weekly intervals but water samples were not collected for analyses of metal concentrations because it was anticipated that they varied substantially at the contaminated site. Although input of metals from the smelter remained reasonably constant, the water of First Creek is subject to variable dilution with Gulf water in response to tidal action. Since the experimental sites were accessible by boat only near high tide, weekly analyses would only represent high tide conditions and not accurately display the range of metal concentrations to which the caged animals were exposed. In the absence of continuous monitoring equipment for the contaminated site, the results of a 12 mo water sampling program at a downstream location, collected over a range of tide heights, were used to estimate the range of metal concentrations in First Creek during periods of normal effluent release by the smelter. At the control site, which receives no metal inputs, the results of the $12 \mathrm{mo}$ sampling program were used to describe the range of metal concentrations to which the fauna would normally be exposed in Fifth Creek. At locations $500 \mathrm{~m}$ downstream of the site in First Creek and $20 \mathrm{~m}$ downstream of the site in Fifth Creek water samples had been collected at monthly intervals for the 12 mo period to April, 1981. Water was collected in a 41 PVC cylinder that had been acid soaked prior to its first use A diver collected the samples by flushing several volumes through the cylinder, then capping both ends. 

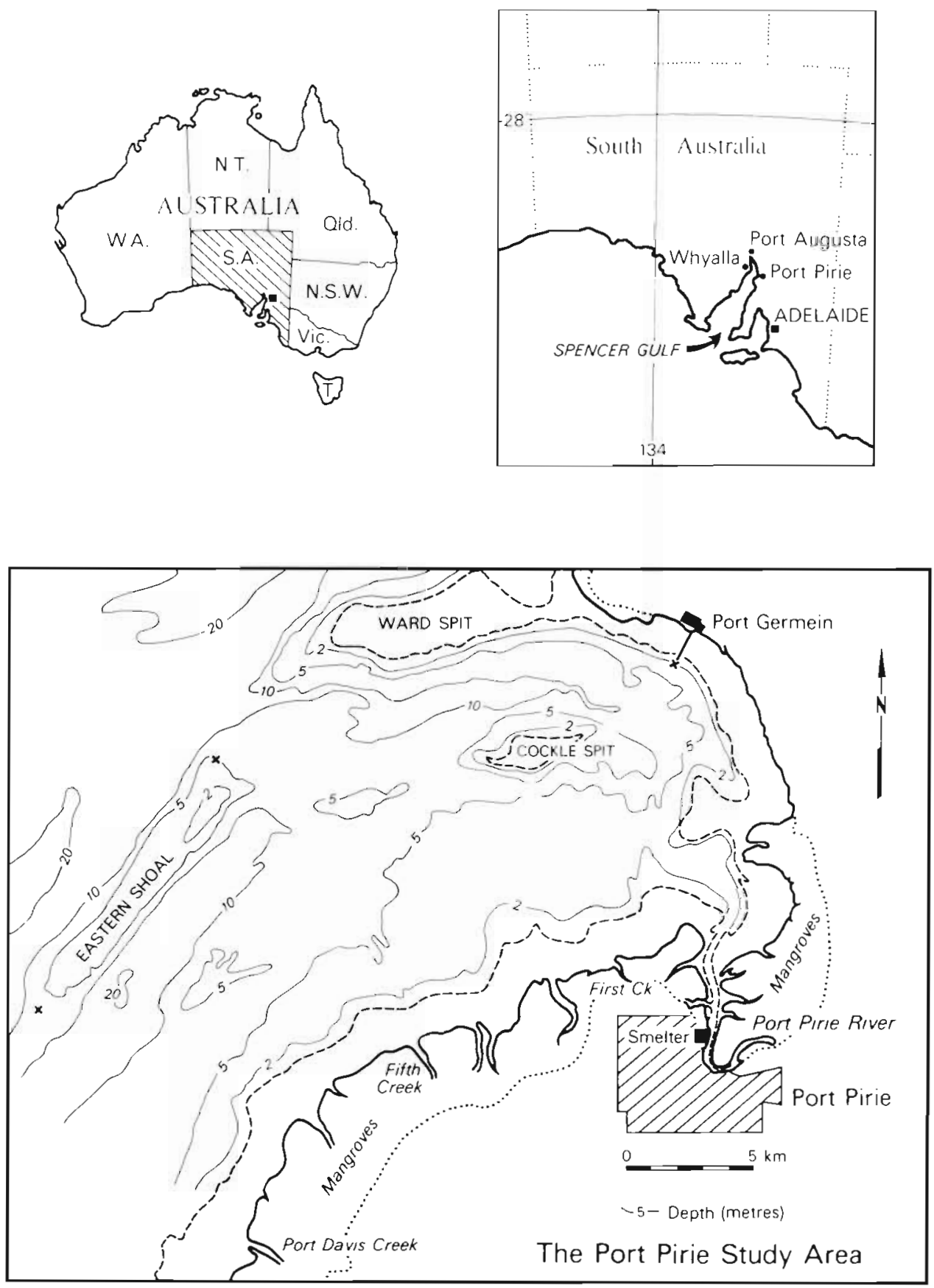

Fig. 1. Port Pirie study area

The samples were filtered $(0.45 \mu \mathrm{m})$ immediately in an acid-soaked all plastic apparatus, the final $250 \mathrm{ml}$ of $1 \mathrm{I}$ filtered was added to a $250 \mathrm{ml}$ polyethylene bottle containing $2 \mathrm{ml}$ of Aristar (BDH) nitric acid, then stored at $4{ }^{\circ} \mathrm{C}$. Extreme care was taken to avoid contamination from boat surfaces and water surface slicks. Diving weights and most other metallic surfaces were sealed by epoxy resins to reduce the potential for field contamination of the samples. In the laboratory the $\mathrm{pH}$ of the stored sample was adjusted using concentrated ammonia (Aristar, BDH), then metals were determined by double freon extraction and back extraction into nitric acid followed by carbon furnace atomic absorption spectroscopy (Danielsson et al., 1978).

Adults of Cymodoce longicaudata (Crustacea: Sphaeromidae) and Favonigobius lateralis (Teleostomi: Gobiidae) and juveniles of Neoodax sp. (Teleostomi: Odacidae) and Helotes sexlineatus (Teleostomi: 
Theraponidae) were used in the experiments. The last 3 species were included in the group of 20 species identified by field survey as affected by the metals (Ward and Young, 1982). These 4 species were chosen for testing because they are reasonably resistant to handling, and as they are the most abundant species sufficient individuals could be collected. Normally, 5 individuals of a species were placed in each cage, and mortalities recorded at weekly intervals for 3 wk. Effective volume of the cages was about 101 , and maximum biomass per cage was less than $10 \mathrm{~g}$. No food was supplied and dead animals were not removed. Water flow through the cages was substantial and this appeared to prevent build-up of excretion products or effects of bacterial growth on the test animals. The results of the 2 experiments have been pooled and presented as cumulative percent mortality in the contaminated area (First Creek) compared to the control (Fifth Creek). Differences between the 2 locations have been determined using the non-parametric Kolmogorov-Smirnov test (Sokal and Rohlf, 1969). The usual transformations of toxicity data are not appropriate here because of the few data points for each experiment and because the experiments were designed for hypothesis testing to provide explanations for previous field results, as distinct from laboratory toxicity tests which seek to estimate population parameters for predictive purposes.

\section{RESULTS}

\section{Metals in water}

The results of the 12 mo water sampling program in First Creek (Table 1) show that not only are the concentrations of dissolved metals much higher than likely background concentrations (Table 2), but also the high standard deviation indicates substantial variability. Since there was a reasonably constant input of metals from the smelter, the main cause for the variation is likely to be different levels of dilution with Gulf water at the sampling site. The major factors influencing the dilution of First Creek water are the height of the high tide (which because of an entrance bar in the Creeks can effectively range from about $2 \mathrm{~m}$ to over

Table 2. Metals in Fifth Creek water (control site) $(0.45 \mu \mathrm{m}$ filtered, $i g ~^{-1}$ )

\begin{tabular}{lllll|} 
& \multicolumn{1}{c}{$\mathrm{Cd}$} & $\mathrm{Cu}$ & $\mathrm{Pb} \cdot \mathrm{Zn}$ \\
\hline $\begin{array}{l}\text { Mean }(\mathrm{n}=12) \\
\text { range }\end{array}$ & 0.22 & 0.63 & 13.3 \\
$\begin{array}{l}\text { Approximate } \\
\text { background }\end{array}$ & $0.04-0.70$ & $0.17-1.39$ & $5.0-29.1$ \\
$\begin{array}{l}\text { (Jan \& Young, 1978) } \\
\text { - Analyses for Pb at low concentrations }\left(<2.5 \mu \mathrm{gl}^{-1} \text { ) were }\right. \\
\text { unreliable (Ward et al., in press) }\end{array}$ & 0.7 & 0.1 & 5.4 \\
\end{tabular}

Table 1. Metals in First Creek water

\begin{tabular}{|c|c|c|c|c|}
\hline & \multicolumn{4}{|c|}{ Metal concentration $\left(0.45 \mu \mathrm{m}\right.$ filtered, $\left.\mu \mathrm{g} \mathrm{l}^{-1}\right)$} \\
\hline & $\mathrm{Cd}$ & $\mathrm{Cu}$ & $\mathrm{Pb}$ & $\mathrm{Zn}$ \\
\hline \multicolumn{5}{|l|}{ Measured concentrations } \\
\hline Mean (s.d.) $\mathrm{n}=12$ & $11.5(19.6)$ & $0.99(0.51)$ & $34.8(33.7)$ & $353 \quad(424)$ \\
\hline \multicolumn{5}{|c|}{ Predicted range of concentrations ${ }^{*}$} \\
\hline High tide $(3 \mathrm{~m})$ & -1 & 0.66 & 3.8 & -8.5 \\
\hline Low tide $(<2 \mathrm{~m})$ & 33.1 & 2.81 & 205 & 2343 \\
\hline \multirow[t]{3}{*}{ 'Dodge' tide (no change) } & - & 8.3 & 722 & 8392 \\
\hline & \multicolumn{4}{|c|}{ Correlation coefficients } \\
\hline & Metal & & & Significance \\
\hline \multirow[t]{4}{*}{ Dilution index $\cdot$} & $\mathrm{Pb}$ & & & $\mathrm{p}<0.01$ \\
\hline & $\mathrm{Cd}$ & & & ns \\
\hline & $\mathrm{Cu}$ & & & $p<0.05$ \\
\hline & $\mathrm{Zn}$ & & & $\hat{\mathrm{p}}<0.01$ \\
\hline Height of high tide & $\mathrm{Cd}$ & & & $\mathrm{p}<0.05$ \\
\hline \multicolumn{5}{|c|}{$\begin{array}{l}\text { Predicted from the correlation of measured water concentrations with a 'dilution index' using } y=a+b x, \text { where } y=\text { metal } \\
\text { concentration; } a=y \text { intercept } ; b=\text { slope (correlation coefficient, } r) ; x=\text { 'dilution index' ( } \mathrm{Pb}, \mathrm{Cu} \text { and } \mathrm{Zn} \text { ) or height of previous } \\
\text { high tide (Cd) } \\
\cdots \text { 'Dilution index' = (number of hours elapsed between high tide at Port Pirie and sampling time) minus (height of high tide } \\
\text { in metres) plus } 5\end{array}$} \\
\hline
\end{tabular}


$3 \mathrm{~m}$ ) and the time of sampling in relation to the previous high tide. As the sampling time approaches high tide maximum dilution would be expected, and as it approaches low tide minimum dilution would be expected. When these 2 factors are combined into a 'dilution index', there is a good correlation between measured concentrations and the index for $\mathrm{Pb}, \mathrm{Cu}$ and $\mathrm{Zn}$ (Table 1). However, concentrations of $\mathrm{Cd}$ correlate only with height of the previous high tide at Port Pirie, and not with the 'dilution index' (Table 1). The fluctuations in metal concentrations occurring in First Creek caused by dilution with Gulf water of lower metal concentrations can therefore be described by a linear model. By extrapolation from the regression equation it has been possible to predict the range of concentrations normally occurring in First Creek. The results of daily water analyses supplied by BHAS show that concentrations of metals in the smelter effluent were reasonably constant during the period of the experiments reported here, and thus the concentrations predicted from the 12 mo water sampling program adequately describe the range of concentrations experienced by the animals caged in First Creek (Table 1).

About once a month ( 3 times during the experimental period) upper Spencer Gulf experiences 'dodge' tides - a period of little change in water level for up to $24 \mathrm{~h}$. Water sampling results have been extrapolated to predict concentrations in First Creek during a 'dodge' tide, when the Creek is usually not influenced by tidal action. Thus, at this time the metal concentrations in the Creek should increase towards those of the smelter's effluent, and the concentrations of $\mathrm{Pb}$ and $\mathrm{Zn}$ predicted for First Creek do approach those supplied by BHAS for the smelter's effluent. Since Cd correlated only to the height of the previous high tide at Port Pirie it has only been possible to predict the normal high and low tide range of concentrations in First Creek (Table 1).

The analysis of metals in water at the control site (Table 2) indicates that all 4 approach background concentrations in Fifth Creek, except perhaps for $\mathrm{Cd}$ which may be slightly elevated.

\section{Toxicity tests}

Two of the species tested - Cymodoce longicaudata and Neoodax sp. - are acutely sensitive to the First Creek water. The remaining 2 - Favonigobius lateralis and Helotes sexlineatus - are not, although greater replication may result in the effect of First Creek water on $F$. lateralis being significant (Table 3). C. longicaudata displays an extreme sensitivity to the water, with more than $80 \%$ dying within the first $7 \mathrm{~d}$.

The effluent from the smelter is largely cooling water pumped from the Gulf and is usually contaminated only with trace metals. Data from daily monitoring by BHAS showed that the metal concentrations and $\mathrm{pH}$ (range 7.3 to 8.1 ) remained reasonably constant throughout the period of the experiments reported here. First Creek salinity and temperature varied only slightly from that of the control area (Table 4), and, since both were near their seasonal minima during these experiments, they are unlikely to have an effect on short-term toxicity of the First Creek water. It is thus highly improbable that factors other than dissolved metals are responsible for the observed increase in mortality of the caged Cymodoce longicaudata and Neoodax sp. in First Creek.

\section{DISCUSSION}

Fishes of the genus Neoodax are extremely common in these seagrass beds. Their acute sensitivity to the metals suggests that, in Spencer Gulf immediately adjacent to First Creek, acute toxicity will play a major role in determining the distribution of this genus. However, both in the highly contaminated area and in the peripheral area, acute toxicity of dissolved metals in water is likely to be exacerbated by consumption of metals in food. Since 2 species of this genus were identified as affected by the metals and to decline in a gradient from least contaminated to most contaminated sediments (Ward and Young, 1982), their distribution is likely to be a complex function of both acute and subacute effects of the metals.

The extreme acute sensitivity of the isopod Cymodoce longicaudata to the metals is surprising since it was not amongst the 20 species identified by field survey as metal-affected. However, this species was by far the most abundant in the study area and a re-examination of the abundance data shows that although changes in frequency were not detected in the contaminated Posidonia habitats (Sites A3 and A4 of Ward and Young, 1982, about $2 \mathrm{~km}$ from the entrance to First Creek), a substantial reduction in abundance occurred in the contaminated Zostera area (1.5 km from First Creek) in both summer and winter. The present results therefore suggest that metals may be largely responsible for this decline in abundance of C. longicaudata. Since C. longicaudata does not show a reduction in abundance at the contaminated Posidonia sites where sediment and water metal concentrations are high (Ward and Young, 1981, 1982), it is likely that there is a threshold for effect of the metals, perhaps associated with the development of tolerance in the population. Tolerance to $\mathrm{Pb}$ induced by brief laboratory acclimation has been described in the freshwater isopod Asellus aquaticus (Fraser, 1980) and it is 
Table 3. Acute toxicity - cumulative percent mortality

\begin{tabular}{|c|c|c|c|c|c|c|c|}
\hline \multirow[t]{2}{*}{ Species } & \multirow[t]{2}{*}{ Location } & \multirow[t]{2}{*}{ Replication " } & \multicolumn{4}{|c|}{ Week } & \multirow[t]{2}{*}{ Significance $\cdot$} \\
\hline & & & 0 & 1 & 2 & 3 & \\
\hline \multirow[t]{2}{*}{ Cymodoce longicaudata } & First $\mathrm{Ck}$ (contaminated) & $\mathrm{n}=30, \quad \mathrm{r}=6$ & 0 & 93 & 100 & 100 & $P \ll 0.01$ \\
\hline & Fifth Ck (control) & $\mathrm{n}=25, \quad \mathrm{r}=5$ & 0 & 12 & 12 & 29 & \\
\hline \multirow[t]{2}{*}{ Favonigobius lateralis } & First $\mathrm{Ck}$ (contaminated) & $\mathrm{n}=8, \quad \mathrm{r}=2$ & 0 & 38 & 38 & 50 & n.s. \\
\hline & Fifth $\mathrm{Ck}$ (control) & $\mathrm{n}=9, \quad \mathrm{r}=2$ & 0 & 11 & 11 & 11 & \\
\hline \multirow[t]{2}{*}{ Neoodax sp. } & First Ck (contaminated) & $\mathrm{n}=20, \quad \mathrm{r}=4$ & 0 & 5 & 15 & 75 & $\mathrm{P}<0.01$ \\
\hline & Fifth Ck (control) & $\mathrm{n}=25, \quad \mathrm{r}=5$ & 0 & 0 & 0 & 0 & \\
\hline \multirow[t]{2}{*}{ Helotes sexlineatus } & First Ck (contaminated) & $\mathrm{n}=15, \quad \mathrm{r}=3$ & 0 & 7 & 7 & 7 & n.s. \\
\hline & Fifth $\mathrm{Ck}$ (control) & $\mathrm{n}=15, \quad \mathrm{r}=3$ & 0 & 0 & 0 & 0 & \\
\hline
\end{tabular}

thus possible that a similar mechanism could be responsible for the distribution pattern of $C$. Iongicaudata observed here.

The results of these experiments show that acute effects of the metals are likely to be responsible for part of the distribution pattern shown by 2 of the 4 species tested. However, the individual metal which contributes most to this toxicity is not known. The results do not permit accurate comparisons between the individual acute toxicities of $\mathrm{Cd}, \mathrm{Cu}, \mathrm{Pb}$ and $\mathrm{Zn}$ to these species but some general observations are appropriate. $\mathrm{Cu}$ is highly toxic to marine fishes and crustaceans but, ignoring metal-metal and metal-environment interactions, it is unlikely to contribute to the acute toxicity observed here since its water concentration does not exceed $0.01 \mathrm{mg} \mathrm{l}^{-1}$ in the highly contaminated area while its $96 \mathrm{~h} \mathrm{LC}_{50}$ ranges from 0.2 to $3 \mathrm{mg} \mathrm{l}^{-1}$ for various marine fish and crustaceans (Bryan, 1976). Although $\mathrm{Zn}$ is less toxic its water concentration in the highly contaminated area (up to $8.4 \mathrm{mg} \mathrm{l}^{-1}$ ) regularly approaches the likely $96 \mathrm{~h} \quad \mathrm{LC}_{50}$ values for some Australian marine fish and crustaceans of about 0.5 to $60 \mathrm{mg} \mathrm{I}^{-1}$ (Ahsanullah, 1976; Negilski, 1976). The highest concentrations of $\mathrm{Cd}$ predicted to occur in First Creek (0.03 $\mathrm{mg} \mathrm{l}^{-1}$ ) are lower than the range of reported $\mathrm{LC}_{50}$ values (about 0.3 to $50 \mathrm{mg} \mathrm{l}^{-1}$; Taylor, 1981). The acute toxicity of $\mathrm{Pb}$ to marine fishes and crustaceans is poorly known and the few literature values suggest that the highest predicted concentrations of $\mathrm{Pb}$ in First Creek (0.7 $\left.\mathrm{mg} \mathrm{l}^{-1}\right)$ do not contribute to the observed toxicity $\left(96 \mathrm{~h} \mathrm{LC}_{50}\right.$ range 300 to 500 mg $1^{-1}$; Westernhagen et al., 1979; Maddock and Taylor, 1980). Therefore, on the basis of laboratory data it appears that $\mathrm{Zn}_{n}$ is most likely to be responsible for acute effects in the highly contaminated area on Neoodax sp. and Cymodoce longicaudata. Nevertheless, outside this highly contaminated area subacute and sublethal effects probably have a substantial impact on the community structure, and here the other metals, through bioaccumulation, selective uptake or greater bioavailability from sediments, may be of equal or greater toxicity.

Juvenile Helotes sexlineatus were not acutely affected by metals in these experiments yet this species was found to be reduced in abundance by metals in the Zostera beds near the entrance to First Creek (Ward and Young, 1982). H. sexlineatus is a grazing fish in the study area and consumes large amounts of epiphytic algae (own unpubl. data). Since the epiphytic algae can contain high concentrations of metals (Ward, 1982) consumption of contaminated food, rather than the acute effects of dissolved metals, is likely to be the main cause of the decreased abundance of this species. Acute metal toxicity to larval $H$. sexlineatus is unlikely to be responsible for any major part of the observed distribution pattern of this species because adults are mobile and could readily extend their range into the contaminated Zostera beds. If this is true laboratory acute toxicity (and these field) tests would not have predicted a hazard to $H$. sexlineatus since such tests almost invariably present the metals in the dissolved form.

Table 4. Salinity and temperature during toxicity tests mean (s.d.); 5 observations at each location

\begin{tabular}{|c|c|c|c|}
\hline \multicolumn{2}{|c|}{$\mathrm{S}(\%)$} & \multicolumn{2}{|c|}{$\mathrm{T}\left({ }^{\circ} \mathrm{C}\right)$} \\
\hline Contaminated & Control & Contaminated & Control \\
\hline $45.7 \quad(0.7)$ & $43.7(0.9)^{\circ}$ & $16.4(1.4)$ & $15.7(1.6)$ \\
\hline \multicolumn{4}{|c|}{$\begin{array}{l}- \text { t test, significantly }(p<0.01) \text { lower than contaminated } \\
\text { location }\end{array}$} \\
\hline
\end{tabular}

The greater acute toxicity of the metals to Cymodoce longicaudata compared to the fishes tested is consistent with literature $\mathrm{LC}_{50}$ data for the effects of some metals on Australian marine fishes and crustaceans 
(Ahsanullah, 1976; Negilski, 1976). However, this result is in contrast to those of our field survey in the study area which concluded, on the basis of number of species affected, that fish were more affected by the metals than were crustaceans (Ward and Young, 1982). In this case field toxicity tests have failed to explain completely the results of a field survey method for assessment of effects of the metals. Since the acute toxicity tests have examined only the short-term effects of high concentrations whilst the field survey has assessed effects resulting from all the possible lethal and sublethal effects, at all life stages, which are manifested in the community structure, the latter is considered to be more accurate for assessment of overall effects. Thus it is apparent that effects of the metals on the distribution and abundance of these seagrass fauna could not have been adequately predicted using the acute toxicity tests.

Although both Neoodax sp. and Cymodoce longicaudata are acutely affected by the metals it is likely that the effects on $C$. longicaudata are restricted to the area near First Creek since further than $1.5 \mathrm{~km}$ from the entrance to First Creek C. Iongicaudata displays normal abundances. This, together with the difference between the results of acute toxicity tests and the ecological survey for $H$. sexlineatus, suggests that, if these 4 abundant species are representative of the seagrass fauna as a whole, acute toxicity will not play a major role in the structuring of this community, even in the highly contaminated area. In the less contaminated area (up to $8 \mathrm{~km}$ from the entrance to First Creek) where metal concentrations are much lower but the metals still affect species abundances, acute toxicity will be even less significant and the subacute and sublethal effects are likely to be mainly responsible for the observed species distributions. Thus, acute toxicity tests using dissolved metals (laboratory or field) are unlikely to be able to predict accurately faunal distribution in metal-contaminated areas, or to provide an adequate basis for the establishment of water quality criteria for the protection of seagrass faunal communities.

Acknowledgements. This research has been supported by the International Lead Zinc Research Organization Inc. Mr. V. Neverauskas was responsible for building the experimental cages, and I am grateful for his skilled laboratory and field assistance. I am also grateful to Dr. P. C. Young, CSIRO Division of Fisheries Research, Cronulla, N.S.W, for numerous discussions and advice, and to Mrs. A. Oliver for careful analyses of metals in seawater. I thank Dr. K. G. Tiller and other staff of CSIRO Division of Soils, Adelaide, for support and advice in analytical problems, and BHAS Pty. Ltd. for the results of their daily water analyses.

\section{LITERATURE CITED}

Ahsanullah, M. (1976). Acute toxicity of cadmium and zinc to seven invertebrate species from Western. Port, Victoria. Aust. J. mar. Freshwat. Res. 27: 187-196

Ahsanullah, M., Negilski, D. S., Mobley, M. C. (1981). Toxicity of zinc, cadmium and copper to the shrimp Callianassa australiensis. 1. Effects of individual metals. Mar. Biol. 64: 299-304

Boyden, C. R., Phillips, D. J. H. (1981). Seasonal variation and inherent variability of trace elements in oysters and their implications for indicator studies. Mar. Ecol. Prog. Ser. 5: $29-40$

Bryan, G. W. (1976). Heavy metal contamination in the sea. In: Johnston, R. (ed.) Marine pollution. Academic Press, London, p. 185-302

Danielsson, L., Magnusson, B., Westerlund, S. (1978). An improved metal extraction procedure for the determination of trace metals in sea water by atomic absorption spectrometry with electrothermal atomisation. Analytica chim. Acta 98: 47-57

Fraser, J. (1980). Acclimation to lead in the freshwater isopod Asellus aquaticus. Oecologia (Berl.) 45: 419-420

Gray, J. S., Mirza, F. B. (1979). A possible method for the detection of pollution-induced disturbance on marine benthic communities. Mar. Pollut. Bull. 10: 142-146

Jan, T. K., Young, D. R. (1978). Determination of microgram amounts of some transition metals in seawater by methyl isobutyl ketone-nitric acid successive extraction and flameless atomic absorption spectrophotometry. Analyt. Chem. 50: 1250-1253

Maddock, B. G., Taylor, D. (1980). The acute toxicity and bioaccumulation of some lead alkyl compounds in marine animals. In: Branica, M., Konrad, Z. (ed.) Lead in the marine environment. Pergamon Press, Oxford, p. 233-261

Negilski, D. S. (1976). Acute toxicity of zinc, cadmium and chromium to the marine fishes yellow-eye mullet (Aldrichetta forsteri C. \& V) and small mouthed hardyhead (Atherinasoma microstoma Whitley). Aust. J. mar. Freshwat. Res. 27: 137-149

Sokal, R. R., Rohlf, F. J. (1969). Biometry. Freeman, San Francisco

Sprague, J. B. (1971). Measurement of pollutant toxicity to fish. III. Sub-lethal effects and safe concentrations. Wat. Res. 5: 245-266

Tarzwell, C. M. (1971). Bioassays to determine allowable waste concentrations in the aquatic environment. Proc. R. Soc. Lond. (Ser. B) 177: 279-285

Taylor, D. (1981). A summary of the data on the toxicity of various materials to aquatic life. 2. Cadmium. Report BL/ A/2073, ICI Brixham Laboratory, Freshwater Quarry, Overgang, Brixham, Devon

Train, R. E. (1979). Quality criteria for water. Castle House Publ., Washington

Ward, T. J. (1982). The distribution of cadmium in shallow marine sediments, flora and fauna near a lead smelter, Spencer Gulf, South Australia. In: Edited Proc. Third Int. Cadmium Conf. Miami, 1981. Cadmium Association, London, p. 88-93

Ward, T. J., Young, P. C. (1981). Trace metal contamination of shallow marine sediment near a lead smelter, Spencer Gulf, South Australia. Aust. J. mar. Freshwat. Res. 32: $45-56$

Ward, T. J., Young, P. C. (1982). Effects of sediment trace metals and particle size on the community structure of epibenthic seagrass fauna near a lead smelter, South Australia. Mar. Ecol. Prog. Ser. 9: 137-146 
Ward, T. J., Warren, L. J., Tiller, K. G. (in press). The distribution and effects of metals in the marine environment near a lead-zinc smelter, South Australia. In: Nriagu, J. O. (ed.) Environmental impacts of smelters. John Wiley and Sons, New York
Westernhagen, H. V., Dethlefsen, V., Rosenthal, H. (1979). Combined effects of cadmium, copper and lead on developing herring eggs and larvae. Helgoländer wiss. Meeresunters. 32: 257-278

This paper was submitted to the editor; it was accepted for printing on January 7,1984 